\author{
Iryna Samatoj \\ DOI: $10.15290 / \mathrm{bb} .2019 .11 .11$ \\ Witebski Państwowy Uniwersytet \\ im. P. M. Maszerawa \\ https://orcid.org/0000-0002-5126-6891
}

\title{
Архетыповыя вобразы ў паэзіі Алеся Барскага
}

Беларускамоўную літаратуру Польшчы цяжка ўявіць без Алеся Барскага (Аляксандра Баршчэўскага). У ім ўдала спалучыліся таленавіты паэт, празаік, перакладчык, гісторык літаратуры, педагог, грамадскі дзеяч. Пачатак літаратурнай творчасці Алеся Барскага прыпадае на сярэдзіну 50-х гадой ХХ стагоддзя, калі актыўна развіваўся грамадска-культурны рух беларускай меншасці у Польшчы. Рэальным плёнам гэтага руху было стварэнне Беларускага грамадска-культурнага таварыства (БГКТ), выданне штотыднёвіка «Ніва» (1956), выпуск штогодніка «Беларускі каляндар» (1957), узнікненне беларускага літаратурнага аб'яднання «Белавежа», выхад шматлікіх калектыўных і аўтарскіх зборнікаў. Літаратурна-культурная сітуацыя беларуска-польскага памежжа, безумоўна, уплывала на станаўленне светапогляду паэта, прадвызначыла ідэйна-эстэтычную скіраванасць яго вершаў, настойлівае памкненне спасцігнуць сутнасць быцця чалавека, асэнсаваць духойную прастору яго існавання. Найбольш удалося зрабіць гэта А. Барскаму ў паэзіі. Сведчанне - вершы, змешчаныя ў кнігах «Белавежскія матывы» (Беласток, 1962), «Жнівень слоў» (Беласток, 1967), «Мой бераг» (Мінск, 1975), «Блізкасць далёкага» (Беласток, 1983), «Лірычны пульс» (Мінск, 1987).

Крытыкай неаднаразова адзначалася шматтэмнасць, шматпраблемнасць паэзіі "белавежца". Кожны з пяці зборнікаў характарызуецца шчырасцю і непасрэднасцю пачуцця, прастатой думкі, схільнасцю да выкарыстання ў сваёй творчасці паэтычных форм і вобразаў. 
Літаратурная дзейнасць беластоцкіх творцаў, у тым ліку і Алеся Барскага, за апошні час неаднойчы параўнойвалася даследчыкамі $з$ дзейнасцю беларускіх адраджэнцаў пачатку XX ст. у плане актыўнага фарміравання нацыянальнага міфастварэння архетыпа нацыі, у кантэксце сусветнай культуры. У творчасці паэта відавочнае месца займае архетып "малой радзімы" - вёскі, якая мае канкрэтную назву - Бандары. Галоўны герой зборнікаў - лірычная асоба, што вырасла на Беласточчыне, назаўсёды захавала ў душы повязь з малой радзімай, яе людзьмі, родным наваколлем. Алесь Барскі перасцерагае тых, хто адракаецца ад сваіх каранёў:

Лёс пакіне нас там, дзе ён толькі захоча,

Але хай ён аслепіць сынам усім вочы,

Калі схочуць яны ці з бяды, ці з раскошы

Прамяняць родны край на хвалу ці на грошы ${ }^{1}$.

Патрыятычныя пачуцці і памкненні скіраваны да родных вёсак, мястэчкаў, дзе да гэтай пары яшчэ можна пачуць беларускае слова.

Таму ӱ творчасці Алеся Барскага - песняра гэтага краю - гучыць асаблівая песня Бацькаўшчыне:

Я толькі на роднай зямлі

Станаўлюся свабодным.

Выключна ў сваіх Бандарах

Да сонца й зямлі

Дастаю адначасна рукамі.

І толькі сярод землякой

I дабро, і святло - мая ўласнасць (ЛП, с. 21)

Родны кут, шчырая любоў да сваёй зямлі - асноўныя матывы твораў паэта $\ddot{y}$ яго першай паэтычнай кнізе «Белавежскія матывы». Большасць вершаў гэтага зборніка - адкрыццё хараства бацькоўскай зямлі, якая дае крылы для паэтычнага палёту. Выразна адчуваецца наследаванне лепшых дасягненняў класічнай беларускай літаратуры i, у прыватнасці, паэзіі Максіма Танка. Захоўваючы памяць страчанага дзяцінства, паэт паўстае першаадкрывальнікам непаўторнага хараства роднага краю, вясковага побыту, які па словах даследчыцы Беаты Сівэк часта пераносіџь у стан міфу, па-за рэальную $i$ гістарычную часапрастору ${ }^{2}$. Так, параўнаем матывы танкаўскага асэнсавання Радзімы ў гучанні верша Алеся Барскага.

1 А. Барскі, Лірычны пульс, Мінск 1987, с. 13. Далей пры спасылцы на гэта выданне ў дужках падаецца: ЛП і старонка.

2 Б. Сівэк, Алесь Барскі. Паклон малой Айчьюе, Мінск 2001, с. 4. 
У Максіма Танка:

Ёсць у сусвеце планета Зямля

Ёсць на Зямлі той краіна адна,

А у той краіне - прыстанішча, дзе

Сэрца званчэйшыя песні вядзе ${ }^{3}$.

У Алеся Барскага:

Ёсць на свеце такая зямля,

Дзе пачатак мой і канец.

Як не верыш, прыдзі ды глянь...

Радасць радасці сэрца кране ${ }^{4}$.

Ідэйная пераклічка вершаў абумоўлена любоўю паэтаў да сваёй Айчыны і ўсяго, што з ёй звязана. Разам з тым, радкі беластоцкага аўтара вызначаюцца ўласнай адметнасцю і самастойнасцю.

Любоў да Радзімы не сузіральнае пачуццё, банальнае любаванне краявідамі. Гэта ўсвядомленае адчуванне трывалай, непарыўнай повязі 3 тым асяроддзем, $з$ якога ён пайшоў у шырокі свет:

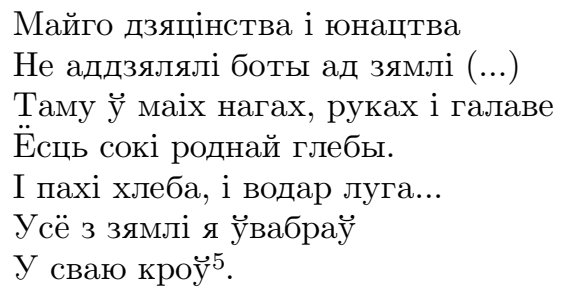

Дамінантнае месца ў творчасці Алеся Барскага займае архетып бацькоўскай хаты, месца, дзе паэт нарадзіўся, дзе адчуй смак хлеба, сеяў зярняты ў раллю, звінеў касою над лугамі, дзе сустрэў каханне, - гэта яго шчаслівы лёс, яго гонар:

Ля ціхай хаты, на галінах,

Таму $\ddot{y}$ маіх нагах, руках і галаве

I гэта ёсць мая Айчына,

Якой спяваю мае песні (МБ, с. 13).

3 М. Танк, Мне пару крыл дало юнацтва, Мінск 2003, с. 112.

4 А. Барскі, Белавежскія матывы, Беласток 1962, с. 11. Далей пры спасылцы на гэта выданне у дужках падаецца: БМ і старонка.

5 Алесь Барскі, Мой бераг, Мінск 1975, с. 54. Далей пры спасылцы на гэта выданне ў дужках падаецца: МБ і старонка. 
Родная хата для паэта - гэта не толькі Бандары, пэўная прастора, a, перш за ўсё, тая субстанцыя, якую стварылі яго маці і бацька, гэта тое месца, па якім ён сумуе і да якога імкнецца ўсёй душой:

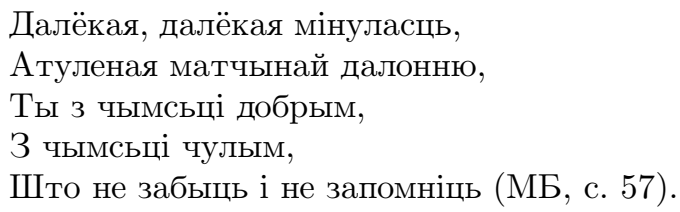

Многія творы паэта напоўнены прыгажосцю роднага краявіду, апісваюць вясковы быт. Так, з вершаў «Парог», "Няўжо ў дзяцінства не вярнуся", «Бела-зялёныя стагі», «Беглі вятры» перад чытачом паўстае тое наваколле, у якім знаходзіцца лірычны герой, і яго пачуцці, перажыванні праходзяць перад вачыма. Пачуццё любові да роднага дому захоплівае сваёй прастатой і шчырасцю:

Не мала прайшоў я дарог, I шляхоў, і нязведаных сцежак. Ды ўспамін пра вясковы парог Аставаўся ў памяці свежы.

Мне сягодня лягчэй уявіць, У чым сіла традыцый і спадчын.

Спеў парога астаўся ў крыві,

Бо ён бацькаў, ён матчын (МБ, с. 15).

Відавочна пераклічка верша Алеся Барскага "Парог" з вершам Максіма Танка Парог, выччасань з успамінаў, // Астаўся за мной.. Архетыповы вобраз парога, як катэгорыі духойнай, набывае акрэслены характар, а вяртанне да яго становіцца галоўнай дамінантай творчасці Алеся Барскага, эквівалентам роднага дома, Айчыны.

Творчы ўплыў Максіма Танка на паэзію Алеся Барскага прасочваецца ў імкненні ахапіць і апаэтызаваць каларытныя дэталі родных мясцін, рэаліі вясковага побыту (вершы "Снапы ляжалі на таку", "На далонях тваіх", “А дзе ж той хлеб...", “Лісты да маткі" і інш.). 3 шэрагу твораў Алеся Барскага, быццам мазаіка 3 маленькіх каменьчыкаў, складваецца панарамны вобраз вясковага жыцця, якое імпануе разнастайнасцю фарбай, багаццем духойнага жыцця лірычных герояў. Побач са знакамітымі вершамі нарачанскага песняра "Аўсяны кісель", "Смаленне кабана", "Стол", "Каб вы паслухалі" яны маглі б скласці этнаграфічна-паэтычную анталогію жыцця сялянскай вёскі. 
Паэт прызнаецца ў сваёй любові Беласточчыне, і гэта гучыць як сапрайдная сынойняя споведзь:

Я сын зямлі беластоцкай.

I іншае мне маці не трэба,

Там рэчкі сінія-сінія

і ветры з далонямі кволымі

бягуць на зялёнай краіне,

як сябры, заўсёды вясёлыя (МБ, с. 69).

Герой паэзіі Алеся Барскага - інтэлігент з сялян, чалавек эмацыянальны і ўражлівы, які спыніўся дзесьці на паўдарозе паміж горадам і вёскай, хоць даўно лічыць сябе гарадскім. Вёска настойліва кліча яго да сябе хараством прыроды, усімі рэаліямі свайго жыцця і побыту. Горад, - прызнаечиа паэт, - завалодаў толькі маёй фізічнай субстаниьяй, але ніколі духоўнай. (...) у яго паэзіі ўвасоблена душа земляроба, душа вясковага чалавека, але з разуменнем горада - душа інтэлігента і сына сваёи зямлі з марамі, імкненнямі, роспаччу, радасчю, спадзяваннямі і надзеямі на лепшае, весялейшае, скажам так, - людскае жьициёб.

Ва ўсей паэзіі творцы высвечваецца сыноўняя адданасць роднай зямлі, тым вытокам, якія ўзгадавалі яго, дапамаглі стаць сумленным чалавекам, навучылі цаніць працу:

Трывогу нашу я ў сэрцы:

Зрабіў для Айчыны так мала,

I сёння гатой памерці,

Каб толькі яна існавала?

Творчае крэда беларускіх пісьменнікаў 50-60-х гг. ХХ стагоддзя «Усе мы - 3 хат!» - не толькі прызнанне, а жыццёвая пазіцыя Алеся Барскага, той вызначальны лейтматыў, які праходзіць праз ўсю яго творчасць.

Надзвычай шырока і арганічна гучыць у лірыцы Алеся Барскага паэтызацыя прыроды роднага краю - крыніцы мудрасці, смутку i радасці. Паэт ідэалізуе прыроду і лічыць сябе яе часціцай. У адным з першых інтэрв'ю малады пісьменнік прызнаўся: Я так глыбока разгубляюся, што нават часта не магу выдзелічь сябе з Белавежы

6 Я. Адамовіч, Вучонь, паэт, грамадзянін, (у:) Культура беларускага замежжа, Мінск 1993, с. 65.

7 Алесь Барскі, Выбраныля творы, Мінск 2011, с. 37 
ў нешта самастойнае. Ці Вам не здаециа, што я з'яўляюся адным з дрэў белавежскіх?

Ад палёу мы сябе не аддзелім,

Не пакінем ніколі дубровы,

Лес нам ложа лістотай пасцеле,

Закалыша лірычнаю мовай (ЛП, с. 58).

Аднаму з першых у беларускай літаратуры паэту ўдалося стварыць эмацыянальныя, пластычныя малюнкі наднарвенскай прыроды, скласці ўрачыста-прыўзнятую оду Белавежскай пушчы. Прыгадаем, што гэты натхнёны вобраз даў назву яго зборніку "Белавежскія матывы”. Узорамі своеасаблівай малітойнай лірыкі з'яўляюцца вершы "Белавежа - анёлаў гурт", "Белавежа, ты, як малітва", "Мой лесе, мой зялёны браце", "Лясы - душа маёй краіны". Архетыповы вобраз пушчы, лесу прысутнічае ва ўспамінах, выклікае настальгію аб мінулым, фарміруе каштойнасныя арыенціры лірычнага героя, дапамагае знайсці ўнутраную раўнавагу. Непасрэдна звяртаючыся да ix, ідэнтыфікуючы сябе са светам прыроды, паэт шчыра прызнаецца:

Я прыйшоў абарваны, пусты і прыбіты, бо горад сарваў рукой дабрабыту з плячэй маіх кужаль. Пушча, мяне не гані ты, Дай вопратку целу, Дай сэрцу дужасць ${ }^{8}$ (ЖС с. 159)

Аўтар уважліва спасцігае зменліва-трапяткі прыродны стан пушчы, якую халоднай далоняй кастрычнік абняў; дзе ногі ў агні па калена; маркочячиа гнёзды ў трысиі; снег елкі па рукі; дыєван травы, усквечаны дажджамі. Прыродныя змены ўслаўлены паэтам у лірычных медытацыях "З-пад снегу зноў", "Белавежская зіма", "Ціхутка з каронаў злятаюць лісты", "Нядзеля, зноў восень у пушчы ў гасцях", "Прычасці мяне, клёне зялёны". Уяўляецца, што храм прыроды - пушча - не прахадны вобраз, а інтуітыўнае адчуванне акаляючага свету, крыніца паэтычнага натхнення:

Змяшаўся я сёння з пушчанскім накцюрнам,

Не знаю, дзе песня, дзе я і дзе пушча (БМ, с. 91).

8 А. Барскі, Жнівень слоў, Беласток 1967, с. 159. Далей пры спасылцы на гэта выданне ў дужках падаецца: ЖКС і старонка. 
Цесная повязь чалавека і прыроды асабліва адчуваецца ў вершах, населеных жыхарамі пушчы - дрэвамі, раслінамі, птушкамі, жывёламі. Трэба адзначыць, што ўключэнне іх у пейзажныя замалёўкі прыводзіць да стварэння глыбока канкрэтнай, знаёмай паэтычнай карціны і служыць сродкам раскрыцця гарманічнага светабачання: $\kappa y$ рапатак пасеяла восень / на полі бульбяным; жураўлі дзесь галосячь / над летам скананым; паходняй рыжай, агністай / мільганула вавёрка ў галінках; $і$ заяи вылеціў з дубровьи, / як моль, у руні дзірку выеў; лісіча рыжая прабегла праз пралеску / не, не лісіча, толькі восень.

Алесь Барскі свядома пазбягае ў вершах прыроднай экзотыкі замежных краін, захапляючыся сціплымі карцінамі, хараством і прывабнасцю родных пейзажаў. Успрымаючы прыроду як нешта жывое, дынамічнае аўтар прадстаўляе яе ӱ адушаўлёных вобразах-сімвалах. Так, клёны, бярозы - браты і сёстры ў каронах, вербы-плачкі - сведкі кахання, вяз - няшчасны закаханы, яліны - пані вяльможныя, елкі - трывожныя субяседніцы. Вобраз танкаўскай сасны $з$ нарачанскага краю, які стаў сімвалічным у беларускай паэзіi, часта сустракаецца ў лірыцы Алеся Барскага як сімвал зямлі беластоцкай:

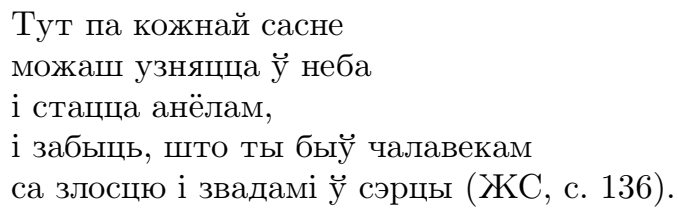

Пантэістычнае светаадчуванне пранізвае пейзажную лірыку, абумоўліваючы важнейшую адметнасць паэзіі Алеся Барскага.

У вершах паэта вельмі моцны сузіральны пачатак - стан самапаглыблення, спакою і душэўнай цішыні знайшоў увасабленне у традыцыйнай структуры вершаванага твора, псіхалагічна насычанай пластыцы, асацыятыўнай вобразнасці, экспрэсіўнай тропіцы, уважлівым стаўленні да дэталяй і падрабязнасцей.

Менавіта праз прызму спасціжэння сутнаснай красы жыцця родных людзей і прыроды ідзе ў паэзіі беластоцкага аўтара асэнсаванне ўласна-спадчыннага, спакавечнага, засвойванне коласаўска-танкаўскай традыцыі выяўленчай малюнкавасці.

У сістэме нацыянальных архетыпаў паэзіі Алеся Барскага вялікае месца займае жанчына, якая паўстае у наступных архетыповых вобразах: жанчына-маці, жанчына-каханая. Усе гэтыя архетыпы у творчасці паэта з'яўляюцца суб'ектыўна пададзенымі, гэта значыць праз яго 
ўласнае ўспрыманне. Праз іх ідзе глыбокае філасофска-мастацкае спасціжэнне жыцця, часу. Звяртаючыся да традыцыйнага ў беларускай літаратуры вобраза маці, паэт шукае яго вытокі ў міфалогіі, фальклоры, дзе маці - сімвал жыцця, сімвал вечнасці. Архетып маці ў творчасці Алеся Барскага годна ўпісваецца ў жаночую галерэю нашай нацыянальнай літаратуры поруч з апаэтызаванымі вобразамі жанчын Якуба Коласа, Янкі Купалы, Петруся Броўкі, Ніла Гілевіча, Максіма Танка, Рыгора Барадуліна. Заўважым, што у творчасці беластоцкага паэта вобраз маці адметны рамантычнай узвышанасцю, лірычнай прачуласцю.

Выключнай шчырасцю, і далікатнасцю напойнены вершы, прысвечаныя высакароднаму вобразу маці, які з'яўляецца сімвалам жаночай дабрыні, ласкі, клопату:

Твой твар быў сонцам над маёй калыскай, якое я крануй рукою, к якому прыглядаўся зблізку (МБ, с. 55).

Большасць вершаў Алеся Барскага напісана ад першай асобы, што сведчыць аб "аўтабіяграфічнасці" сюжэтаў і вобразаў. У сваёй публіцыстычнай кнізе "З пабачанага і перажытага" ён, узгадваючы мінулае, шчыра прызнаецца: Прайшло многа часу з таго дзячінства. Ужо чатырначиачь гадоў не жьве мая мачі. Аднак яе вобраз не зблякнуў $i$ не пачямнеў у маёй удзячнай памячі. Асабліва ў часе бяссонных начэй, а часта і ў снах бачу яе пры кудзелі, дзяжы, жорнах. Бачу незаменную, незабыйную і святую. Мучанічу, якая пусціла мяне на вольнь свет, надзяліўшы пэўнымі ўласиівасиямі, дзякуючь якім магу аддзялічь дабро ад зла і ўвасобіліся ў пранікнёных паэтычных радках:

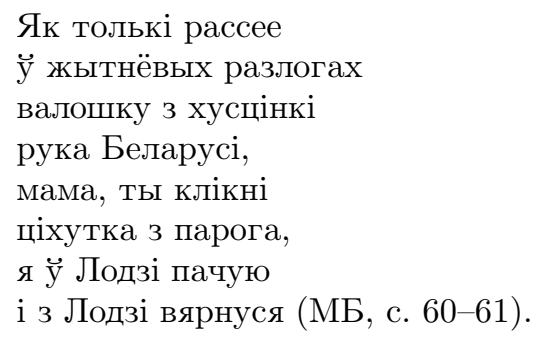

9 А. Барскі, 3 пабачанага і перажытага, Мінск 1992, с. 16. 
У вершах Алеся Барскага маці паўстае ў вобразе жанчыны-працаўніцы, захавальніцы сямейнага дабрабыту, вернымі спадарожнікамі якой былі иіхі спеў калаўрота; пах прэлага жыта на печьл, маленькі серпік; бруістая песня-быліна для сына. Жыццесцвярджальныя рысы святла і цяпла ўласцівы паэтычнаму вобразу жанчыны-маці, асабліва, калі гаворка ідзе пра яе рукі, вочы, усмешку - дамінуючыя мастацкія дэталі, якія дапамагаюць паэту ўзнавіць дарагі з маленства воблік.

Рукі маці у вершах Алеся Барскага ("Шчырыя рукі растуць проста з сэрца", "Колькі разоў рукі маці прагналі трывогу", "Ліст да маткі") маюць сілу сонца: яны саграваюць і ахоўваюць, ім ён прыпісвае абстрактныя пачуцці: шчырасць, пяшчотнасць, чуллівасць:

Колькі раз рукі маці прагналі трывогу, Колькі раз паказалі у шччасце дарогу, колькі раз адагналі з парога вы голад, колькі раз абагрэлі у с сњжу і холад, колькі раз былі цішай і сном на павеках, колькі раз павучалі як быць чалавекам (ЖС, 70$)$.

Ва унісон гэтаму вершу гучаць радкі Рыгора Барадуліна, які ўвекавечыў у беларускай літаратуры вобраз сваёй маці Куліны Андрэеўны:

Нам прыпомняцца рукі матчыны, Што люлялі калыску, рукі.

Тыя добрыя рукі першымі

Ад зямлі нас паднялі у угору ${ }^{10} \ldots$

У сталым узросце Алесь Барскі шукае позірк маці, яе вочы, якія з'яўляюцца самымі дарагімі:

I зноў дзяцінства

Радасны блакіт,

Матчын з-пад далоні

Позірк сіні

Шукаю я канца

Бясконцае ракі,

Хоць скроні серабрыць

Халодны іней (ЛП, с. 83).

10 Р. Барадулін, Збор твораў. У 5-ці т. Вершы, Мінск 1996, т. 1, с. 29. Далей пры спасылцы на гэта выданне у у дужках падаецца: Б. і старонка. 
Сузор'ямі дабрыні і цяпла бачацца мацярынскія вочы ў паэтычных радках Рыгора Барадуліна:
Вочы твае
Нада мной узышлі
Сузор'ямі цішыні,
Сусветамі дабрыні... (Б., с. 216)

Вобраз маці праходзіць праз усю творчасць паэта, канкрэтызуецца і набывае новыя рысы. Маці паўстае Мадоннай, Святой Заступніцай, паэт шукае яе падтрымкі у спасціжэнні Айчыны і вяртанні да родных вытокаў, чакае матчынай малітвы супрачь злосці, хваробы $i$ войнаў $i$ бітвай, неўраджаяў... (ЖС, с. 69), просіць абароны ад чорнай зграі бяспамяцтва:

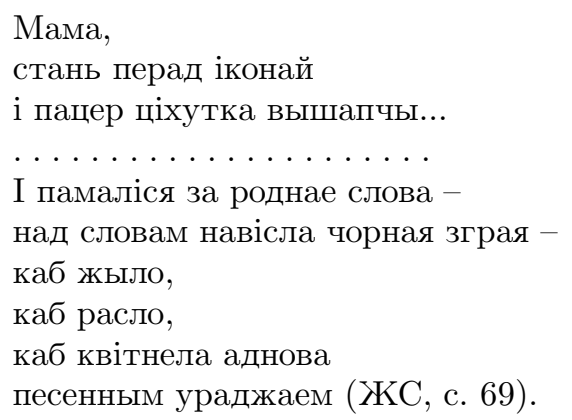

Рускі літаратуразнаўца і фалькларыст Я. Меляцінскі лічыць, што дзякуючы міфалагічнаму архетыпу "маці - дзіця" пераадольваеича ўлада часу, адзінкавая свядомасиь $i$ асобнь лёс уздымаюииа да нейкага архетыпу жаночай долі $i$ бессмяротнасиі ${ }^{11}$ Гімн жанчыне і яе долі гучыць у вершах А. Барскага "Ліст да маткі", "Матчын хлеб", "Як лета пакліча...", "Бі мяне біткай". Увасабленнем ахвярнай і святой любові з'яўляецца постаць маці, не выпадкова вылучаная творцам у архетыповыя сімвалы сваёй паэзіі.

У зборніку "Жнівень слоў" вобраз маці яднаецца з вобразам малой радзімы - Беласточчыны і набывае ўзвышанае, маштабнае значэнне. Да архетыпу маці далучаецца архетып Маці-Зямлі - прарадзіцелькі уссяго жывога.

Уменне напоўніць змест твора ўніверсальным сэнсам, праз уласнае, асабістае закрануць і ўсхваляваць чытача адчуваецца у драматычных радках памяці роднага чалавека:

11 Е. Мелетинский, Поэтика мифа, Москва 1995, с. 68. 


\section{I чорны я,}

Як ноч начэй у лістападах,

Бо не магу сказаць

Ніколі болей - Мама ${ }^{12}$.

Паэт успамінае матчыны слёзы і надзеі, з пакораю гаворыць пра свае нягодныя ўчынкі і памылкі, просіць за іх прабачэнне:

...прабач усё тое, матуля, што сам я сабе не прабачу (ЖС, с. 65).

Матыў прабачэння, раскаяння гучыць і у паэзіі Рыгора Барадуліна:

$$
\begin{aligned}
& \text { Даруй, што спазніўся } \\
& \text { Пачуць тваё апошняе слова... } \\
& \text { Даруй, што шчырасць тваю } \\
& \text { Выстуджвай, як сівер, сурова }{ }^{13} .
\end{aligned}
$$

Паэтычны вобраз у паэзіі Алеся Барскага выступае як адзіная форма існавання думкі і перажывання. Адным з асноўных архетыпаў у лірыцы паэта з'яўляецца вобраз маці: яго разнастайныя архетыпічныя ўяўленні. Па-першае, маці-ахоўніца сямейнага дабрабыту, па-другое, захавальніца роднага слова, аберагальніца традыцый, па-трэцяе, маці атаясамліваецца з вобразам малой радзімы - Беласточчыны. Усе гэтыя архетыпічныя ўвасабленні ўстойліва прысутнічаюць у паэтычнай канцэптасферы творцы.

У мастацкім кантэксце паэзіі Алеся Барскага архетыповы вобраз каханай жанчыны паўстае як увасабленне чалавечнасці, вышэйшай праявы адухоўленасці свету:
Ты створана небам, Шчодрай яго жменяй, Пахнеш навальніцай, Сонечным праменнем. Ва ўсім свеце гэтым Толькі ты адна (ЛП, с. 110).

У нізцы "У глыбіні вачэй тваіх зялёных" далікатна, ва ўсеабдымным сваім пачуцці, з налётам таямнічасці і загадкавасці паэт малюе вобраз Яе, поўны асалоды незабыўнага, непарайнальнага. У вершах “Ты

12 А. Барскі, Блізкасиь далёкага, Беласток 1962, с. 28.

13 Р. Барадулін, Маўчанне перуна: Новая кніга, Мінск 1986, с. 61. 
была, як гронкі вінаграду", "Цябе стварыў Бог”, “Ты - белая бяроза маіх сноў" вобраз жанчыны раскрываецца паступова, у параўнанні з навакольным краявідам, з'яўляецца сінонімам да слой шчасце, каханне, лёс. Лірычны герой Алеся Барскага нястомны ў слоўных доказах вернасці каханай, у захапленні яе вонкавай і душэўнай прыгажосцю:

\author{
Усе мае радасці \\ I ўсе мае смуткі \\ Выплываюць з адной крыніцы. \\ Ты яе пачатак \\ I яе канец \\ Адначасна (ЛП, с. 114).
}

Каханая жанчына $\ddot{y}$ паэзіі Алеся Барскага часта выступае на фоне прыроды. Характэрная асаблівасць гэтага фона - яркія, сонечныя вясновыя вобразы: светласиь ранняя, квецень вясны, добрая просінь, васільковасиь матчынага неба пакідаюць надзею на ўзаемнае пачуццё і радасць сустрэчы. I нават ноч, спадарожніца закаханых, у вершах "У гэтую чорную ноч", "Ніколі гэтай ночы памяць не пакіне" падкрэслівае таямнічасць пачуцця, інтымнасць узаемнай блізкасці, а не спрыяе роспачы і безнадзейнасці.

Бязмежная радасць у вершах пра каханне саступае месца лёгкаму суму, расчараванню, журбе. Паэт сцвярджае, што сапраўднае пачуццё не можа існаваць без болю, без трагедыі ("У тваім каханні я не бачу болю"). У вершах з цыклу "Настальгіi", напісаных у час расстання 3 каханай жанчынай, аўтар 3 непадробным лірызмам разважае над сутнасцю і сэнсам кахання. Пераадольваючы трагедыйнае светаадчуванне, Алесь Барскі далікатна разважае пра трывожнае, выпрабаванае часам, інтымнае пачуцце маладых людзей ("Ствараю цябе, як яблыня яблык", "Замест пасагу", "Хацеў бы аб табе", "У табе ёсць такое святло"). 3 налётам таямнічасці і загадкавасці паэт стварае вобраз жанчыны, якая прыцягвае сваёй прыгажосцю і далікатнасцю, робіць мужчыну багатым духоўна, упрыгожвае яго жыццё:

3 тваёй рукі

Бяру я промні

I вышываю імі

Сваю дарогу (ЛП, с. 109).

Рамантызаваны вобраз жанчыны з'яўляецца сімвалам і адначасова рэальным адбіткам свайго часу і выкліканага ім настрою. Гэты вобраз 
пераадольвае адлегласці, творыць гімн каханню, без якога і з якім, па словах Алеся Барскага, Яћ жабрак я ўбогі, - i, як князь, я багать (ЛП, с. 112].

Такім чынам, у творчасці беластоцкага паэта прадстаўлены ўстойлівыя архетыпы, першавобразы: Радзіма, родная хата з парогам-мяжой, пушча, жанчына-маці, жанчына-каханая. Праз іх ідзе глыбокае, філасофска-мастацкае спасціжэнне жыцця, яны нясуць абарону і ратаванне, выконваюць функцыі духойнай тэрапіі для заклапочанага сучаснага чалавецтва.

\section{I T E R A T UR A}

Adamovič Â., Vučony, paèt, gramadzânìn, [u:] Kul'tura belaruskaga zamežža, Mìnsk 1993 [Адамовіч Я., Вучонь, паэт, грамадзянін, [у:] Культура беларускага замежжа, Мінск 1993].

Baradulìn R., Zbor tvoraŭ u 5-cì, t. T. 1. Veršy, Mìnsk 1996 [Барадулін P., Збор твораў у 5-ці, т. Т. 1. Вершы, Мінск 1996].

Baradulìn R., Maǔčanne peruna: Novâ̂ kniga, Mìnsk 1986 [Барадулін P., Маўчанне перуна: Новая кніга, Мінск 1986].

Barskì A., Belavežskiâ matyvy, Belastok 1962 [Барскі А., Белавежскія матывьи, Беласток 1962].

Barskì A., Blìzkasc' dalëkaga, Belastok 1983 [Барскі А., Блізкасць далёкага, Беласток 1983].

Barskì A., Žniven’ sloǔ, Belastok 1967 [Барскі А., Жнівень слоў, Беласток 1967].

Barski A., Z pabačanaga i peražytaga, Minsk 1992 [Барскі А., 3 пабачанага і перажытага, Мінск 1992].

Barskì A., Lìryčny pul's, Mìnsk 1987 [Барскі А., Лірьıныь пульс, Мінск 1987].

Barski A., Moj berag, Minsk 1975 [Барскі А., Мой бераг, Мінск 1975].

Sìvèk B., Ales' Barski. Paklon maloj Ajčyne, Mìnsk 2001 [Сівэк Б., Алесь Барскі. Паклон малой Айчыне, Мінск 2001].

Meletinskij E., Poètika mifa, Moskva 1995 [Мелетинский Е., Поэтика мифа, Москва 1995].

Tank M., Mne paru kryl dalo ûnactva, Mìnsk 2003 [Танк M., Мне nару крьıл дало юнацтва, Мінск 2003]. 
S U M M A R Y

\section{ARCHETYPICAL IMAGES IN ALES BARSKI'S POETRY}

The author of the article investigates stable archetypes in Ales Barski's Belarusian poet - oeuvre. She points out that all archetypical images are subjective, i.e. created through the author's perception. Ales Barski addressing images of home, forest, matter that traditionally function in Belarusian literature looks for the origin in mythology and folklore. They help to find philosophic-artistic understanding of life, time and creative beginnings. It is emphasized that archetypes perform the function of mental therapy for preoccupied modern mankind.

Key words: literature of Belarusian-Polish border, author, archetypical images, lyrical poetry, oeuvre, style. 